\title{
CULTURAL APPROACH OF SUSTAINABILITY IN DWELLINGS CULTURE RIPARIAN COMMUNITY MUSI RIVER PALEMBANG
}

\author{
WICAKSONO, Bambang ${ }^{*}$, SISWANTO, Ari ${ }^{2}$, KUSDIWANGGO, Susilo ${ }^{3}$, \\ ANWAR, Widya Fransiska Febriati ${ }^{2}$ \\ ${ }^{1}$ Department S3 Engineering Science Post Graduate Program, Sriwijaya University, \\ Jalan Palembang Prabumulih Km. 32 Inderalaya (OI) \\ ${ }^{2}$ Department Architecture Engineering, Sriwijaya University, \\ Jalan Srijaya Negara, Bukit Lama, Ilir Barat I, Kota Palembang, Sumatera Selatan 30128 \\ ${ }^{3}$ Department Architecture, Faculty of Engineering, Brawijaya University, \\ Jalan Mayjen Haryono 167 Malang Jawa Timur 65145 \\ *Corresponding author: bambangwi@live.com
}

\begin{abstract}
Dwelling Riparian is not an archaeological artifacts or ruins of civilization, but the physical figure of communities that are still alive and live. Socially, the Musi River not merely as a means of transport and make a living alone. Moreover Musi River Palembang form of existence of cultural sovereignty. Riverside settlements are not only inherent elegance spatial pattern alone, but also contains exemplary values, philosophy, and belief in the primordial Palembang riverside cultural background and meaning of culture. The goals of this study are, 1) to observe the evolution processes of dwelling culture and to compare the traditional spatial forms and the transformed ones. 2) to emphasize the former attitude and to propose a sustainable strategy for developing the dwelling type by respecting and adopting the traditional culture and historic apologue. The concrete tactics for construction and architectural concepts are proposed in this paper.
\end{abstract}

Keywords: Culture; dwelling; sustainable; riparian.

\section{INTRODUCTION}

The existence of local cultural identity becomes more important amid the current development process that is more directed at the modernization and tends to diminish the local culture system by adopting the science and technology in this era of globalization. (Purnama, 2008). Musi River as the second longest river in Sumatra after the Batang Hari River, into the pulse and bastions Srivijaya kingdom. Musi River is a big river estuary eight other rivers, namely Sungai Kelingi, river Lakitan Rawas River, Batang Hari river Leko, Semangus river, river Lematang, Ogan River, and the river Ogan. Nine territories drained by the river is called the land of the nine rivers (Collins, 2007). Hulu Sungai Musi River continued to Ketapang originating in Bukit Daun protected areas. Musi River flows from the Strait Bangkasepanjang Kepahiang up to $720 \mathrm{~km}$. Musi River divides the city of Palembang relative is in estuary into two regions, namely North Seberang Ilir and Seberang Ulu to the south. They become different occupation groups with one another. Similarly, some groups of people passed the Musi River, such as cluster Besemah relatively in the inland, also has developed a culture and civilization with distinctness respectively. Various groups of the group have the cultural characteristics and/or different and distinctive subcultures, although still in the context of river basin Musi.Setidaknya there are twelve groups of the population, namely Ogan, Palembang, Gumai, Semendo, latitude, Kayu Agung, Lematang, Ogan, Pasemah, Sekayu, Rawas, and Banyuasin.

Various groups of the population to form clans settled in one group. They move, inhabit, habitable, and strengthen cultural generations habitable (dwelling culture) along the banks of the Musi River. Differences in population groups that make up the country and who is not, make the products of their culture, especially on aspects of the building can be divided into two perspectives. Cultural output on the cluster communities forming the country can be seen in the great tradition (grand design tradition) which eventually freezes into traditional nature, while groups of society instead of forming the country can be seen in the category of folk tradition (folk tradition) which boils down to the nature of the vernacular (Rapoport, 1969). Do a diverse group of residents along the banks of the Musi River as a scattered mosaic that can be assembled into a portrait of the living culture intact?

Housing development by mass activities or by individuals continues to grow very fast. Locations for housing development actually takes dry land but in some areas in Palembang, the housing development takes swampy areas, tidal areas, river banks and also 
the body of the river. The goals of this study are, firstly, to observe the evolution processes of human settlement and to compare the traditional spatial forms and the transformed ones. Secondly, a goal is to emphasize the former attitude and to propose a sustainable strategy for developing the dwelling type by respecting and adopting the traditional culture and historic apologue. The concrete tactics for construction and architectural concepts are proposed in this paper.

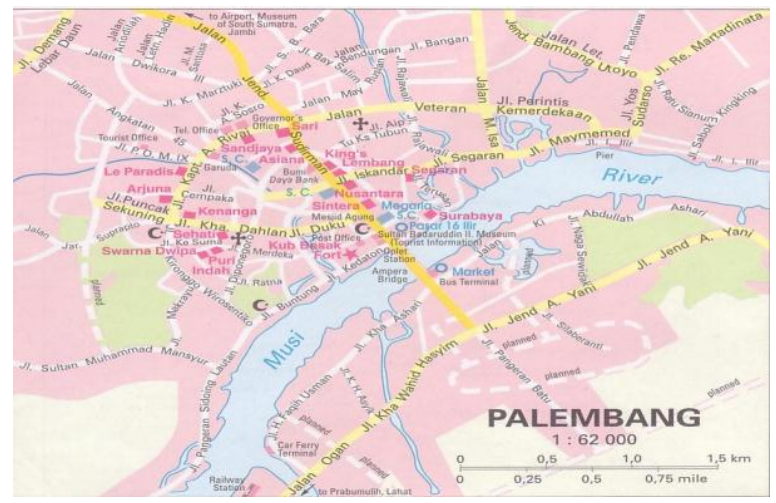

Fig. 1. The map of Palembang

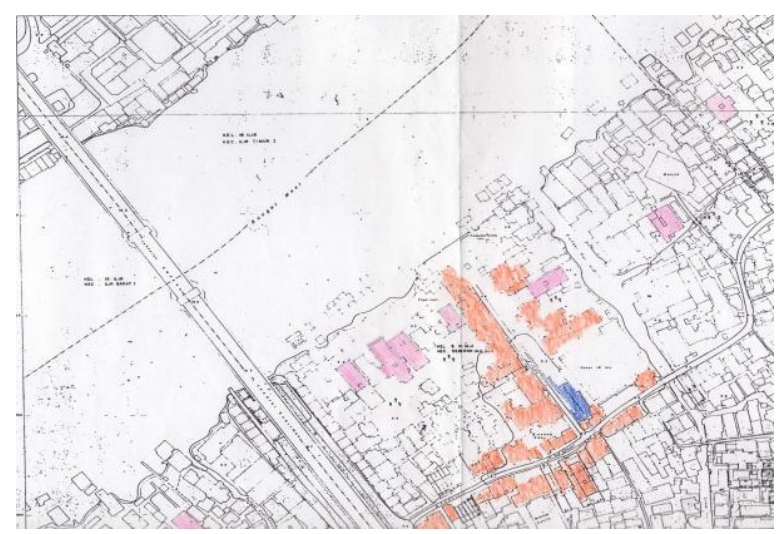

Fig. 2. The geographical description of Musi River after Ampera Bridge built

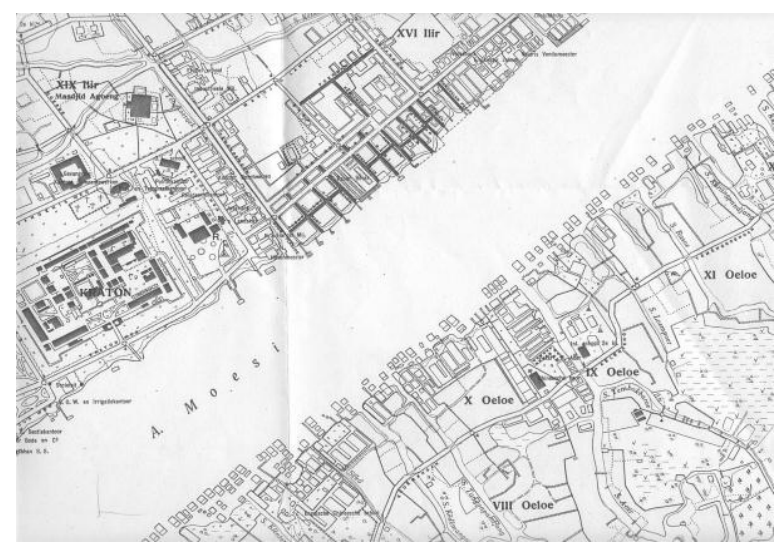

Fig. 3. The geographical description of Musi River before Ampera Bridge built

\section{TRADITIONAL DWELLINGS OR RIPARIAN COMMUNITY MUSI RIVER}

As a culture, building settlements and its constituent elements can be categorized as work of vernacular architecture. The term vernacular architecture shows its association with native peoples, ethnic, folk, farmers, and traditional architecture itself. In the context of the environment and the resources available, they are usually the owner or a community built, using traditional technology. All forms of vernacular built to meet specific needs, accommodating values, economic and cultural way of life that produces them (Oliver, 1997: xxi-xxiii). Vernacular settlements related to the activity of living (dwellings) with different types of livelihood (livelihood) locally. Meanwhile, housing river bank can be understood as a settlement which has a life of agriculture, economic life, and social life depends on rivers, creeks, or channels in which the location and placement of the settlement are closely related to the geography of the river (Davis in Oliver, 1997: 157). In turn, residents living activities will reflect the culture and civilization of the river.

Table 1. Land topography of the state of 1990

\begin{tabular}{clrc}
\hline No & \multicolumn{1}{c}{ Soil drainage } & Size (Ha) & Percent (\%) \\
\hline 1 & Not waterlogged & $10.009,4$ & 47,76 \\
2 & Flooded day after rain & 444,3 & 2,12 \\
3 & Flooded tidal influence & 308,1 & 1,47 \\
4 & Flooded seasonal & $2.366,1$ & 11,29 \\
5 & Flooded continuous & $7.829,8$ & 37,36 \\
\hline
\end{tabular}

(Source: Hanafiah, 2006: 57)

The dominance of the water environment can be seen in the topography of Palembang, which shows that the percentage of land is less than swamps and streams because it reaches more than $50 \%$ (Table 1). The culture of living (dwelling culture) community banks of the River Musi (riparian) is the domain of research that has not been encroached upon. Banks of Musi River is the locus categories based on geographic position. Several studies related to the living cultural locus other geographies, among others, Tana Toraja, Bali, Kampung Naga, Minangkabau, South Nias, and Dayak Kenyah (Wiryomartono, 2014). Some of the settlements are scattered in the archipelago just summarized into a comprehensive local knowledge (Waterson, 1990). While the research culture of living based on a peak-peak local culture which is owned by the settlements.

In living culture, traditional people have always depended primarily on the river for their livelihood, a fact which is reflected in their unique culture. 
Palembang not only have the traditional home Limas, the other is home Rakit, houses and homes Limas Warehouse. Warehouse Limas is a blend of house and home storage. Palembang Darussalam Sultanate in the past to give effect to the existence raft houses located on the banks of the river Musi. As the center of government, Palembang called or considered as an Area of Ilir (downstream) whereas the territory which lies outside the so-called Regional Ulu Palembang (upstream). The presumption is to give effect to the traditional designations home form especially for the traditional home located outside of Palembang, which is referred to as the home of Ulu. Regional geographical conditions also have an influence on the shape of a traditional house that includes aspects of architecture, construction, building materials and philosophy. Although some types of traditional houses have the form of houses on stilts, but each has a different type of stage house structure system that is adaptive to the surrounding environment. Likewise, the home raft according to the area has many large rivers. (Siswanto, 2009).

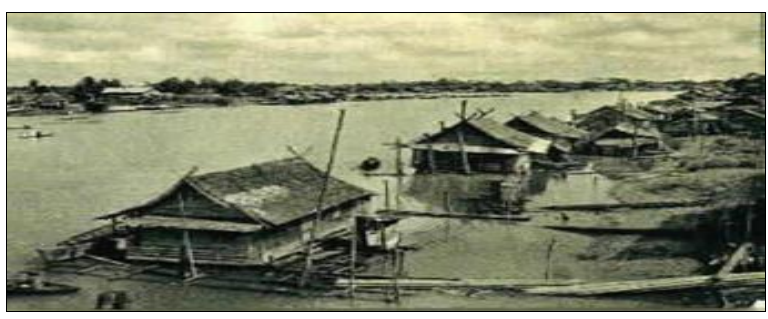

Fig. 4. Raft House in Musi Riverside, Palembang

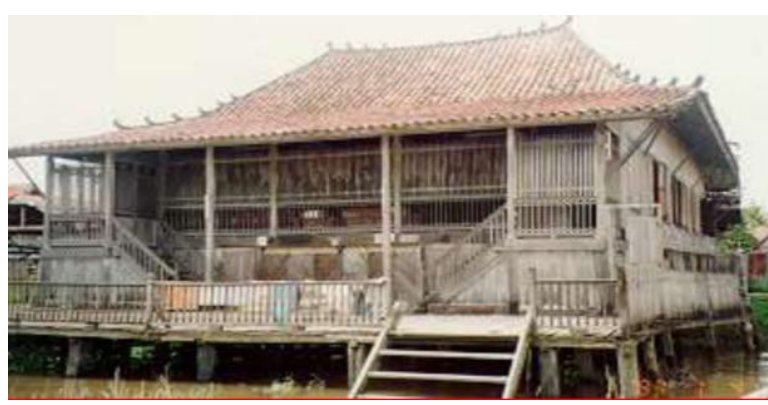

Fig. 5. Limas House in Musi Riverside, Palembang

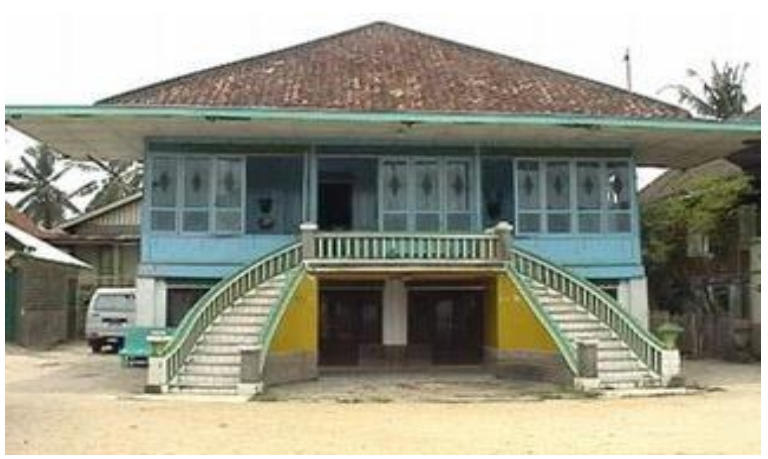

Fig. 6. Warehouse in Musi Riverside, Palembang
According to the South Sumatra Regional Traditional Architecture (1991), the front of house limas are no windows between the two front doors; walls that form the spokes of wood with the translucent motif. The situation is quite effective for wind circulation even though utilization sunlight is less than optimal. Furthermore, at home Limas also a fan who Lawang can be opened fully at the door serves as the ceiling.

In the kingdom of Srivijaya, the settlement is an institution communion where patronage and paternalist formed by the traditional social structure and feudalistic. The entire system is located in one environment and location. This system is known as Guguk. Each Guguk has sectoral nature or aspirants. Just to understanding though not identical, form Guguk (Institute patronage) can be seen with the guild system of the Middle Ages in Europe. Guguk grouping is distinguished by business sector, based on residence or status in society, and by function. Policy on the residential areas is also based on a zone by the social status of society. The leaders placed on the plateau and the building is surrounded by a canal that connects to the Musi River and its tributaries. While the ordinary people living in the house rafts float on the river Musi. The following figure shows a map of the area the Kingdom of Sriwijaya Palembang and location as the center of the kingdom the Musi River (Taim, 2002).

For residential areas, the Sultanate of Palembang classifies based on ethnicity, social status, economic, religious, and position in government. The empire's elite and relatives placed on the plains ilir high in the area. Meanwhile, immigrants like the Chinese people, Arab and Persia mingle with native communities Palembang mostly from Malay race. Immigrants formed their respective communities, live together in a region and set the village on the banks of the Musi River. Acculturation saw also on building their home. Various ornaments condensed particular ethnic culture fused with house shape limasan as a form of house indigenous Palembang. Here are a few photos residential building communities of ethnic Chinese, Arabic, and Malay on the River Musi. During the Dutch colonial administration, the policy regarding the region residential zoning remains classified ethnic based on imposed. Residential neighborhood that has existed since time Palembang Sultanate such as Kampung Kapitan, Kampung Arab, and Kampung Native Palembang is still maintained on the banks of the Musi.

While the newly developed residential area Dutch East Indies government in the higher ground by adopting the concept of a garden city, with the typical building surrounded by a spacious courtyard. However, the system Guguk region preexisting 
fractured into several smaller villages. The aim was twofold: to break the power of the Sultanate of Palembang also divisive society was subject to the sultanate system be subject to administrative Belanda. Other Guguk break, the Dutch colonial government also explicitly halve the administrative region into an area of Palembang Ulu Seberang and Seberang Ilir separated by the Musi River. Each of these areas led by Demang.

At the beginning of the division, Palembang consists of 52 villages. 16 Seberang village located in 36 villages in Ulu and Ilir Seberang. Kampongs are numbered; numbers are 1 to 36 Ilir to Ilir, and 1 to 16 to Seberang Ulu Ulu. However, in 1939 the number of villages to shrink into 43 pieces, ie 29 villages located in Seberang Ilir and 14 villages located in Seberang Ulu. Some villages that number a little soul merged and headed by a village head. Head of Kampung just takes care (Salura, 2014). Hanafi (1988) cited Sevenhoven, explaining that the settlement house has Rakit in Palembang to the inhabitants of most of the Malay ethnic Chinese and foreigners more. Raft settlements to flourish because it is associated with the current regulations Sultanate that. Sevenhoven explained that the Chinese people are allowed to reside in Palembang if they are willing to live on the water, in this case, the river. Palembang ruler considered that if people living in mainland China possible that could endanger the country so that they required to stay on the water, residing on a raft made of bamboo and wood, easily controlled by simply burning rafts that. Settlement on the raft occurs because of the rules, not because you want from originally. Nevertheless, the settlements on the raft, which later developed as like settlements on the mainland. On the other side, Sevenhoven explained that the Europeans at first too residing on the raft. "Situated in the middle of the river water flowing these houses by itself cool and besides that, it can catch the fresh wind from all directions. The presence of water in the nearby river next would facilitate the maintenance of cleanliness, a prerequisite for health. Sitting in the foyer of the rafts Europeans was fun, the good time early in the morning, or just before the cool night. "Although called a raft, where they live is actually home to float like rafts. The house should not be built on the mainland. Thus, the requirements as a permanent home are realized.

\section{CULTURAL APPROACH OF SUSTAINABILITY}

Sumatra Island has not only Musi River as the land of nine rivers, but many other rivers, even bigger and longer. From the north to the south of Sumatra
Island lie Rokan River, Siak River, Kampar River, Indragiri River, and Batang Hari River. In each river magnet lives groups of people or communities with diverse cultures and civilizations. Further studies are required to make long-chain data. However, the study can be explored to the other fields rather than only in the vernacular area. Study related to the living culture in the riparian of Musi River is potentially replicated and induced in other rivers in Sumatra. The replication may enrich Indonesian cultural wealth. What about other rivers outside Sumatra. The replication of this study will surely possible. One of nation civilization comes from river basin. With an inventory of cultural diversity, local knowledge consciousness will be more complete.

Culture riverside living in a dynamic concept, the Indonesian context is not merely seen as the heritage, but also something that is being created. Culture riverside living not merely the reality of the past and pride, but also imperative future arranged in a cultural strategy. No matter how dynamic culture, as a product of human culture can be investigated and researched settled. Culture resides not a symptom that is always changing, but also made an impression in certain patterns. These patterns can be observed and described in the form of an exposure. To approach our culture need to freeze the concepts of static and public. Furthermore, to understand the reality that is happening in the culture. Cultural portrait removed from its frame and let the images live to be settled dynamic cultural exposure.

Culture riverside living can be approached in two properties. First, the approach is static, that is by analyzing the elements of living culture and approach those elements as a whole are interrelated. Second, the approach is dynamic, that is by looking at living culture as a dialectical process. With this distinction cultural analysis more simplified. In the process of freeze culture, living culture can be detailed and assessed in four major aspects, namely (1) in which the human aspects of culture resides in the light of the subjective and objective; (2) aspects of the participation of members of the group of the elements of living culture in which the level of involvement can be seen in three levels, both universal, special, and alternative; (3) aspects of the disclosure in the patterns explicitly or implicitly; and (4) the universal aspects of culture that includes language, knowledge systems, social organization, systems and technology equipment life, livelihood systems, as religion, and the arts.

\section{METHODOLOGY}

This type of method is used: a qualitative explorative (Creswell, 2008); or the nature of the research 
categories: descriptive (Groat \& Wang, 2002). This study is conditioned as a research with a qualitative approach through case study strategies. Research steps built on inductive logic where theorization is built from the bottom. This study will look at cultural diversity, diversity of traditions and diversity criteria. Therefore, this study tends characterized idiographic. Data collection method used, ie observation or archives, accompanied by details of the use of such methods. This study focused on the search for the meaning of the concept of culture settled on the banks of the Musi society. The purpose of this study is to explore the cultural significance settled to unload, reveal, and open concept living culture in order to maintain the values of community and identity in society groups Musi river bank and/or its tributaries. None of three main study references with a qualitative approach using case study refer to the €oral documents (Stake, 1995; Merriam, 1998; Yin, 2003). It always refers to the written documents. Yin even calls it explicitly as a physical artifact. In fact, oral tradition In Indonesia is strongly applied. If the focus of collecting data only refers to written documents, the results tend to be biased.

In qualitative research, all data has an equally important role. Theoretically, generalizations or labeling is often inapplicable because of the presence of slight and neglected data. Oral tradition is the main color of Indonesian culture. A rhyme is actually the oral tradition, not written. Some folklores are also hereditary narrated. They are usually a legend, myth, and genesis of a settlement. In 1970's, the oral tradition began to be frequently documented. Oral data was often underestimated because it was considered as unscientific data. However, qualitative research gives it spaces.

In this study, oral data cannot be underestimated. Oral data is used as one of the important category data which is collected in order to disclose, reveal, and open the concept of living culture in the riparian of Musi River and its tributaries. Oral data is usually covert and considered as taboo. Nevertheless, it can be a reference in studying about living culture. Oral data usually reveals one of the philosophy in people's belief.

Data oral will be standardized into a text in the static culture. From the text, the meaning will be explored. However, it becomes rigid in the context of culture. A study was done by Jong (1952) and LeviStrauss (1963) about settlements in Minangkabau use dual organization in reading the texts. Oral data translation is immersed in its culture mentality and latently narrated about their activities. It causes more comprehensive but emic data analysis is necessarily required. So, one of novelty element of this study is the presence of oral data as the major component of the research data.

Camille Wells (1982), stated that the study of vernacular architecture has evolved over the last ten years (1970-1980) by leaps and bounds in under influence theories and methods of cultural geography, sociology, folklore, and in particular the social history and anthropology. Researchers recognize the building as a cultural artifact to be studied more intensive. Often found that the method of field research (ethnographic) into methods or approaches in the study of vernacular architecture.

Many studies of vernacular architecture that uses field research methods, among other things; (1) Gerald L. Pocius (1982), which uses field study supported with structural analysis; (2) Orlando Ridout V (1982), which has a group of participants consists of architects, folklorist, and social historian. In his research, some buildings recorded by the participants based on significance, damage, and accessibility. Very detailed field notes were used in interpreting and analyzing the entire building; (3) Piyalada Devakula (1999) which uses ethnographic field techniques such as participant observer (participant observer) and free interviews (unstructured) to know the identity of the quality of the experience and meaning in traditional Thai house in its original context and present; (4) Lai (1999) cross-cultural approach multidisciplinary researching architecture traditional in Southeast Asia are very heterogeneous. The approach was chosen because (1) can be applied to cross-sectional study design and correlation; (2) allows a comparative analysis of several different social entities, and (3) do a more holistic analysis and in-depth study on the subject because of the multidisciplinary nature.

In the future research of vernacular settlements will be many challenges. There are three guidelines that have to be concerned in the study of vernacular architecture (Asquith \& Velingga, 2006). First, the vernacular architecture should be treated explicitly as a cultural process, rather than as a product of material only. The tradition of vernacular (vernacular tradition) are dynamic, generated through a dialectical interaction and constantly on the properties of static and dynamic; precedent and creativity; stability and innovation. This interaction allows the tradition to change according to time and place, but still, has a meaning that is relevant in the present. Acceptance of the dynamic nature and adaptative the vernacular tradition open up opportunities for the development of the scope of the study of the vernacular. Thus the vernacular meaning will open a new tradition. Second, the vernacular future research should emphasize the integrative approach, combining the 
perspectives and methodologies from various academic disciplines, applying the theoretical and empirical comparison, focuses on the dynamic interrelationship between building traditions, cultural identity, and living culture. Third, research vernacular architecture in the present must always be criticized and forward, taking into account the success and failure of vernacular traditions, and avoid the tendency of romanticism and exoticism.

Some studies related to the Musi River has been started and is at least an insight into this study was undertaken. Some of them are research settlement at the mouth of the breech area (Nugroho, 1999). Nugroho (1999) intends to identify the characteristics of traditional housing Musi River estuary with the aspect of philosophy and physical formation of settlements. Nugroho (1999) concluded that the settlement of the estuary in Breech is the custom products that can be developed into an attractive location for tourism. Meanwhile, Siswanto (1999) vernacular settlements in South Sumatra such as home and home limas raft of the corner of the building and system structure. While the material point of view, Barendregt (1997) highlights the architectural changes in the migration process in the highlands of South Sumatra. Based on approach comparative analysis on the different architectural traditions in the region of South Sumatra and through the eyes of its own public groups traditionally said (folklorist), resulting puyang as one insight in spatial orientation. Locus Barendregt research is in Pasemah \& Serawai with some cases of home, such as home victimizing, bari house, and the house ulu. In a more specific scope, Taal (1997) saw the change and diversification of functions on a pyramid house in Palembang. Under the influence of building materials and function, house limas are always changing. Social change impacts on cultural aspects. In line with social change, the level of public preference towards smaller families, more practical and modern has contributed to the shift function pyramid house. Limas house less and less special and important in expressing the status of the owner.

\section{RESULTS AND DISCUSSION}

Kampong Al Munawar, 1 ULU, 2 Ulu, 3/4 Ulu, 5 Ulu, 7 Ulu and the others is settlement Musi riverside part Seberang Ulu Palembang. It is mostly populated by a nonindigenous people called the Uluan. Some thousand people inhabit the riverside with a unique human settlement, living culture, society system and natural landscape, which are explicitly different from the main riverside Musi Palembang.
For riverside Musi Palembang, in the past, the spatial change and environmental impact were inconspicuous. The Riparian people remained the most primitive but sustainable of Palembang's nonindigenous community. Nowadays, when the traditional and indigenous culture, environment, and settlement are transformed by external culture, ecological invasion, and inappropriate policies; there is also a rapid change of the characteristic living style and dwelling types. The traditional housing units seem in danger of extinction, replaced by the government or self-built square concrete boxes. The old houses have nearly disappeared from several of the riverside's villages. Compared to the other villages, Kampong Arab, 3/4 village, and the others was lucky to keep its own tradition components of settlement. In recent years, the completeness of this village becomes the most competitive when tourists are beginning to show their interest in the indigenous culture and originality of the tribe. In fact, to be a sustainable living environment on the riverside, both the convenience and the traditional culture should be taken care on the same level. How to define an appropriate strategy and feasible principles on dwelling development could be the most important assignment for the authority and the professionals. We can conclude that several factors affect the new living space after analyzing numerous cases. They are external culture, change of living habit, modernization and climatic factors. Each factor can lead to the change of the space or the component of dwellings. Even for the new buildings that cannot obtain the sufficient site conditions to remain the same configurations as the traditional ones, some indispensable space element and building should not be neglected, like the platform for the quotidian use especially in summer time, and the working house which provides alternative uses for the young people and informal communication. Figure 2 shows a complete organization of a dwelling. More details of the design principles and more effective items can be established based on the different considerations for the architecture plan of new dwellings.

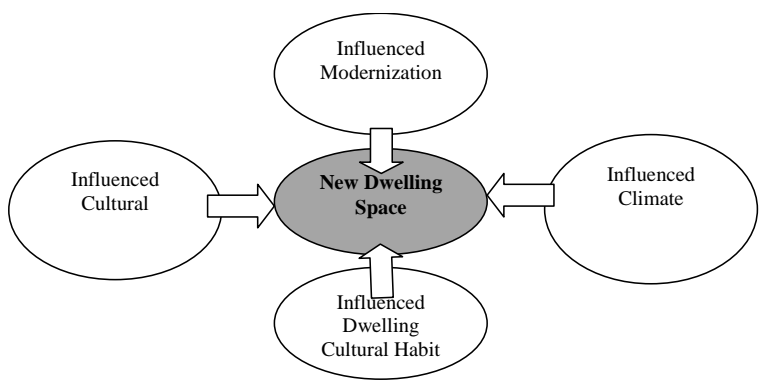

Fig. 7. Factors affecting new dwelling space (Source: Analysis, 2016) 
The original human settlement in dwelling culture riparian Musi River Palembang inspires in us the meaning of a sustainable primitive society, where the indigenous culture, natural landscape, and the tribe ethics rely on each other. Nowadays, in order to response to different external impacts, the dwelling development becomes a complicated phenomenon on the riverside Musi Palembang. Various consequences can be seen in the same village and on the same sites. They are the conservation, the adaptation and the transformation of the village all at the same time. The main challenges for the Riparian people will be: how to guard their own traditions without ignoring the modernization, how to utilize the modern technology without abandoning the ancient wisdom with nature and how to increase the living quality without forgetting the spirit of the living culture.

The original human settlement in riparian people Musi Palembang inspires in us the meaning of a sustainable primitive society, where the indigenous culture, natural landscape, and the tribe ethics rely on each other. Nowadays, in order to response to different external impacts, the dwelling development becomes a complicated phenomenon on the island. Various consequences can be seen in the same village and on the same sites. They are the conservation, the adaptation and the transformation of the village all at the same time. The main challenges for the Riparian people will be: how to guard their own traditions without ignoring the modernization, how to utilize the modern technology without abandoning the ancient wisdom with nature and how to increase the living quality without forgetting the spirit of the living culture.

\section{CONCLUSION}

Riparian people of Musi Riverside are the most original human settlement for Palembang that is almost intact and represents an important human culture and a unique landscape. The riparian can be taken as a typical sustainable milieu for human settlement. Due to the inappropriate policy (such as the different stages of housing development project and the storage program of waste water) and the socio-economic impacts, the traditional settlement is at the crossroads of compromising the different values between indigenous culture and external impacts.

Although traditionally lived by the river reflects the outstanding examples of vernacular architecture, changing rooms and buildings of this type, however, unavoidable due to the introduction and acceptance of modern life. How to keep the idea of sustainable and traditional intelligence, applying them to a new generation of living space should be the most important task for people riparian. This paper describes the evolution of human settlements and housing construction is based on the actuality of the river bank and tried to propose the concept and principles of design to define a new residence.

The Traditional architecture of riparian people Musi River Palembang, though they are not much published is indeed in abundant. Palembang region has dynamical topography which ranges from river, swamps, lowland, and highland. In Palembang, there are various traditional houses, which corresponds to the characteristics of topography, ethnic, and location. Those traditional houses are Limas and Raft house in Palembang, Vernacular settlement of Palembangbased on their characteristic shows the ability of local knowledge to adapt to the environment. For example, Limas house and Raft house which have a specific foundation.

\section{REFERENCES}

Albert, R. \& Jeong, H. (1999). Diameter of the World-Wide Web. Journal of Nature, 401, p.130-131.

Asquith, L. \& Velingga, M. (2006). Vernacular Architecture in the Twenty-First Century: Theory, Education, and Practice. Taylor and Francis Group.

Barendregt, B. (1997). Architectural Transformation in the Process of Migration The South Sumatran Highlands, in Transformation of House and Settlements in Western Indonesia: Changing Values and Meaning of Built Forms in History and the Process of Modernisation. Leiden: Leiden University.

Berry, M.W., Dumais, S.T., O’Brien, G.W., Jefferson, T. \& Owen, L. (1995). Using linear algebra for intelligent information retrieval, SIAM Review, 37, p.573-595.

Creswell, J.W. (2007). Qualitative inquiry and research design: Choosing among five approaches. $2^{\text {nd }}$ Edition. Lincoln: University of Nebraska.

Egenter, N. (1997). Etnographical, in Paul O. (ed). Encyclopedia of Vernacular Architecture of the World. Chambrige University Press, p. 34-35.

Hanafiah, D. (1988). Palembang Zaman Bari Citra Palembang Tempo Doeloe, Humas Pemerintah Kotamadya Daerah Tingkat II Palembang.

Kuo, S.T. \& Chen, C.J. (2009). The Sustainable Dwelling Development of Human Settlement on Orchid Island, Sustainable Development, and Planning, 4(1), p.363, WIT Transactions on Ecology and the Environment, 120, WIT Press, 
www.witpress.com, ISSN 1743-3541 (on-line), http://www.witpress.com/Secure/elibrary/papers /SDP09/SDP09035FU1.pdf, Date Accessed: 28-09-2016 time 19.38 WIB.

Salura, P., Alfred, D. \& Tobing, R.R. (2014). Identifikasi Fisik Arsitektur Kawasan Permukiman Etnis Tepi Sungai Musi Kota Palembang Berdasarkan Aspek Peraturan. Lembaga Penelitian dan Pengabdian kepada Masyarakat Universitas Katolik Parahyangan.

Siswanto, A. (1999). Vernacular Settlement of South Sumatra as an Answer to Settlement Problem Arised Today in Vernaculat Settlement: The Role of Local Knowledge in Built Environment. Seminar Proceeding. Depok: UI.

Siswanto, A. (2009). Kearifan Lokal Arsitektur Tradisional Sumatera Selatan Bagi Pambangunan Lingkungan Binaan, 1(1), p.37-45.
Taal, S. (1997). Change and Diversification in the Function of the Limas House of Palembang, in Transformation of House and Settlements in Western Indonesia: Changing Values and Meaning of Built Forms in History and the Process of Modernisation. Leiden: Leiden University.

Taim (2002). Permukiman Tepi Sungai Di Kota Palembang Dari Masa Ke Masa, Jurnal Siddhayatra, 7(2), p.25- 40.

Wells, C. (1986). Old Claims and New Demands: Vernacular Architecture Studies Today. Perspectives in Vernacular Architecture, 2, p.1-10.

Wiryomartono, B. (2014). Perspectives on Traditional Settlements and Communities: Home, Form and Culture in Indonesia. Springer. 